\begin{tabular}{|c|c|}
\hline $\begin{array}{r}\text { ARTICLES } \\
\text { ARTICULES }\end{array}$ & $\begin{array}{l}\text { CONVERGENCE } \\
\text { AND TRANSMEDIA } \\
\text { STORY'TELLING IN } \\
\text { JOURNALISM: Transformations } \\
\text { in Professional Practices and Profiles }\end{array}$ \\
\hline $\begin{array}{r}\text { Copyright } \odot 2015 \\
\text { SBPjor / Associação } \\
\text { Brasileira de } \\
\text { Pesquisadores em } \\
\text { Jornalismo }\end{array}$ & $\begin{array}{l}\text { ELAIDE MARTINS } \\
\text { Universidade Federal do Pará, Brazil }\end{array}$ \\
\hline
\end{tabular}

\begin{abstract}
As the focus of research developed by Jenkins (2009), convergence culture brings changes to journalism; it affects the practices, routines and profiles of its professionals and their relations with the public. One example is TV Folha from Brazil, a program made by professionals in different areas using press equipment and objectives. Their convergent nature affects production processes and favours hybridization of languages and multiplatform production, accentuating the presence of transmedia storytelling; a term adopted by Jenkins to refer to a model which emerged out of media convergence. This study adopted a qualitative methodology using interviews and observational analysis in order to understand the effects convergence culture has on the way journalism is done and the profile of its professionals. This discussion leads us to believe that the challenge is more than just multiplatform production; it is in the relationships developed out of convergence.
\end{abstract}

Keywords: Convergence. Transmedia Storytelling. Journalism. TV Folha.

\title{
CONVERGÊNCIA E NARRATIVA TRANSMÍDIA NO JORNALISMO: transformações nas práticas e no perfil dos profissionais
}

RESUMO - Foco das pesquisas desenvolvidas por Jenkins (2009), a cultura da convergência traz mudanças ao campo jornalístico, afetando as práticas, rotinas e perfil de seus profissionais e as relações destes com o público. No Brasil, um exemplo é a TV Folha, um programa feito por profissionais de várias áreas, com equipamentos e pautas do impresso. Sua natureza convergente afeta os processos produtivos e favorece a hibridização de linguagens e a produção multiplataforma, acentuando a presença da narrativa transmídia (transmedia storytelling), termo adotado por Jenkins para referir-se a um modelo surgido em resposta à convergência de mídias. Neste trabalho, adotouse metodologia qualitativa, com entrevistas e análise observacional, para buscar compreender como a cultura da convergência afeta os modos do fazer jornalístico e o perfil dos profissionais deste campo. Uma discussão que leva a crer que o grande desafio vai além da produção de conteúdo multiplataforma: está nas relações desenvolvidas a partir da convergência.

Palavras-chave: Convergência. Narrativa Transmídia. Práticas jornalísticas. TV Folha. 
CONVERGENCIA Y NARRATIVA TRANSMEDIA EN EL PERIODISMO: transformaciones en las prácticas y en el perfil de los profesionales

\begin{abstract}
RESUMEN - Foco de las investigaciones desarrolladas por Jenkins (2009), la cultura de la convergencia trae cambios al campo periodista, afectando las prácticas, rutinas y perfil de sus profesionales y las relaciones de estos con el público. En Brasil, un ejemplo es la TV FOLHA, un programa hecho por profesionales de varias áreas, con equipamientos y pautas del impreso. Su naturaleza convergente afecta los procesos productivos y favorece la hibridación de lenguajes y la producción multiplataforma, acentuando la presencia de la narrativa transmedia (transmedia storytelling), termo adoptado por Jenkins para referirse a un modelo surgido en respuesta a la convergencia de medios de comunicación. En este trabajo, se adoptó metodología cualitativa, con entrevistas y análisis observacional, para buscar comprender como la cultura de la convergencia afecta los modos del hacer periodismo y el perfil de los profesionales de este campo. Una discusión que lleva a creer que el grande desafío va más allá de la producción de contenido multiplataforma: está en las relaciones desarrolladas a partir de la convergencia.

Palabras-claves: Convergencia. Narrativa Transmedia. Prácticas periodistas. TV Folha.
\end{abstract}

\title{
INTRODUCTION
}

Wrapped up in convergence culture (JENKINS, 2009), the production processes in journalism have been undergoing a metamorphosis in the digital age, changing the routines and profiles of its increasingly multifaceted professionals. In this context, the participation of the public in production processes has created an even more interactive and media-based relationship between user and journalist. As a result, journalists have been forced to deal with many challenges, among which the task of selecting and formatting material produced by users, therefore redefining the role of Gatekeeper; a term used by David White in 1950 to refer to the individual who selects the news that will or won't be published. A redefinition of sociologist Gaye Tuchman's Newsmaking approach is evident here.

This approach seeks to understand the entire process behind selecting and producing news; and not just the selection criteria. It looks at two points: the professional culture and the organization of work and production processes (WOLF, 1999) in order to describe how the organization of work and its production processes influence 
the social construction of news (PEREIRA JR., 2005). Journalists share a set of rules, routines and conventions among each other that build up their professional culture (TRAQUINA, 2001).

So convergence culture, when included in a praxis about journalism, expands on those two points and simultaneously creates new challenges and builds new narratives in this field. One of these challenges is the need to develop new skills and to broaden the technological field of multiplatform production which is one area of convergence that journalists are most concerned about. In the past, journalists were able to work in the media outlet of their choice, but now they have to produce for various outlets at the same time which means they are required to have the diverse skills associated with them.

Therefore, the profile of the contemporary journalist must understand the different forms of production in media and be able to format the same news story for each one of them. This brings us to the concept of professional polyvalence presented by Salaverría (2010), which presents three variants of polyvalence in journalism: functional, thematic and media-based. Functional polyvalence refers to multitasking, in other words an accumulation of roles; thematic polyvalence is a non-specialized form of journalism, which is done by journalists who are proficient in a broad range of topics for several editorials; and media-based polyvalence is the ability to work with many media forms at the same time within the same company, as is the case for professionals who work at TV Folha.

The trend of multiplatform production in media means businesses lean towards versatile professionals. One result of this convergence is TV Folha in Brazil. It is a program designed for the internet with objectives, editorials, press equipment and professionals that was also broadcast on television over a two-year period. The program was released online in 2011 and, on March 11 2012, it began broadcasting on Sunday night national television on TV Cultura. It was broadcast simultaneously, in real-time, on both the Folha.com website and the CMais (TV Cultura) website with online access to its program blocks.

On April 13, 2014, TV Folha went back to broadcasting exclusively online on the Folha de São Paulo (FSP) and UOL websites (as well as on its YouTube channel and Facebook profile) with hopes of becoming "the largest internet video channel among Brazilian newspapers", according to the last program that was aired. This new phase raises some concerns mainly because TV Folha has gone back 
to being an exclusive online product after already having won three awards ${ }^{1}$ for its television programming.

After leaving TV Cultura, TV Folha restructured its format (it stopped being its own program, with hosts and program blocks, and just started posting articles like many online television stations do) and changed its periodicity from weekly to daily. According to the FSP, TV Folha achieved its television goal of creating a "culture of video journalism in writing by creating an innovative format of traditional journalism and increasing its audience by 65\%" (FSP, 2014). There were two reasons behind the decision to leave television:

\footnotetext{
The decision to take this experience and the videos and go exclusively online was to meet the growing demand online users have for this type of content on journalism websites. It also aims to meet the growing demand in advertising of linking ads to videos on the web (Folha de Sâo Paulo, Caderno Poder, p.14, April 13, 2014).
}

The real reasons behind the change and alterations that have been made to current production processes and the journalists' routines at TV Folha are as of now still unknown, but they are being researched for future work. In this article, we analyze and systematize data that had already been gathered before this change took place, when the program was being produced for both the internet and television. Through the analysis of dozens of reports produced over the course of 2013 - 2014, we look to identify the possible changes that convergence culture has made to journalism processes as well as to professional polyvalence.

Accordingly, this article is the result of a case study built on observational analysis of the product itself and interviews with its team members. A study that promotes discussion and leads us to believe that the major challenge in contemporary journalism goes beyond multiplatform production: the challenge is in the relationships developed out of convergence.

\section{MULTIPLATFORM PRODUCTION: SOMETHING NEW IN THE AIR?}

TV Folha is one of the few audio visual products created for the internet that subsequently migrated to an open television broadcaster; it is even perhaps the only one in Brazil to have made that move to an open and public broadcaster. Even after going back to broadcasting 
exclusively over the internet, its objectives are still shared by the press and contribute towards building a transmedia narrative.

Transmedia storytelling is a term adopted by Jenkins (2009) in his theory of convergence culture and refers to the unfolding of news stories on multiple media platforms, each one of them contributing "differently to our understanding of the universe" (JENKINS, 2009, p. 384). It therefore deals with stories told on several media yet at the same time interconnected by an approach which is "much more integrated to the development of a franchise than the models based on original texts and accessory products" (JENKINS, 2009, p. 384).

In his research on the theory of convergence culture, Jenkins looks to analyze the effects of convergence on popular culture in order to better understand how convergence impacts the media that people consume. His goal is to verify "some of the ways in which convergent thinking is reshaping popular American culture, in particular, its impact on the relationship between the public, producers and media content" (JENKINS, 2009, p. 39). Therefore, for Jenkins, convergence must be assimilated from the interconnectivity that people have with new media, understanding it as a cultural process. By convergence, he refers to "the flow of content across multiple media platforms, the cooperation between multiple media industries and the migratory behavior of media audiences" (JENKINS, 2009, p. 29).

For Jenkins, in the universe of media convergence all consumers are courted across multiple media platforms since the flow of content through different media systems depends on the active participation of the consumer. He goes on to say that consumers are encouraged to seek out new information and make connections between apparently dispersed media content, and convergence therefore represents a cultural transformation which lies within social interaction, establishing new relations with the public. These relations set the conditions for transmediality which, according to Jenkins (2009), occurs when the narrative is dispersed across one media form to another, built autonomously yet understood by the public regardless of the media form used to access it.

Transmediality is the relationship between stories connected by the same plot and narrated on different media - as in the case of TV Folha and the FSP newspaper. Conditions for transmediality favour technological advancements in production, for example TV Folha uses the same equipment for printing as they do for audio visual; photographing and filming with DSLR (Digital Single-lens Reflex) ${ }^{2}$ cameras. Compact and 
lightweight, this equipment gives more freedom, mobility and a new aesthetic design especially for hybridization of languages as program director João Wainer (2012) observes:

\begin{abstract}
When the 5D cameras [Canon] came out, I felt that the two languages, once running parallel with each other, were now fusing together and that's when I knew a new language had been born. I then suggested that Folha set up a project that would be like having a documentary production company inside the Folha newsroom, using the photographers as cameramen in order to try and create a language different from the conventional one we're used to seeing when the printed press or the internet media make videos. I wanted to bring another format, the documentary, something a little less instructional than television journalism and more free to have something a bit more elaborate, to have a slightly better taken photograph (WAINER, 2012, video ${ }^{3}$.
\end{abstract}

This construction of a new language is supported by the 5D camera's attachable accessories such as its interchangeable lenses that give improved lighting, plasticity and image texture. Versatile and less pricey than other models, the 5D was released at the end of 2008 and was soon adopted by video producers in Brazil, causing professionals to broaden their job descriptions. For example, photographers go on to shoot film and cameramen take photographs. "It is a material that newspapers use in photography. So, it's great for transmedia. You can do everything at the same time", explains Douglas Lambert (2013, skype ${ }^{4}$ ), a graduate in medialogy and editor at TV Folha. The program also assigns scripts, art, production, photography, reporting and direction.

The versatility in equipment made changes to production in journalism. For example, when the Folha group set up a video production unit in the printing press newsroom, it was the newspaper reporters who ended up doing the audio visual, changing routines and production forms, languages, storytelling and relationships whether between journalists and users, journalists and colleagues, journalists and the company, or even the journalists themselves.

So what happens when a colleague takes on a function? The Code of Ethics of Brazilian Journalists states that a journalist may take on more tasks but there must be a justifiable reason for it and compensation must be paid (Chapter IV, Art. 14). However, this is not the situation we find in the vast majority of newsrooms that adhere to components of polyvalence and/or convergence. Furthermore, we should look at the methods journalists use to produce news and the transformations they have had to 
experience as a result of changes to production. We need to understand that the procedures behind journalism nowadays are taking on new forms and modifying the way companies are organized. The old distribution of functions and work gives way to the combination of skills and multitasking of a professional whose profile (as previously mentioned) fits Salaverría's (2010) concept of professional polyvalence. When looking at the positive and negative aspects of this mode of convergence in production, editor Douglas Lambert (2013) points towards autonomy as one of its advantages:

An editor is capable of editing the material - and the end result is very different from a reporter's. The person who edits has a background in visual arts, or cinema, or graphics, or anything to do with illustration. How the material looks will be a reflection of who put it together, which reporter's no longer do. You no longer follow a script that puts importance on the narration and the image illustrating the narration. So, a lot of our end result comes from that, comes from the fact that the content of the material does not necessarily dictate how it is put together. This can be bad or good, but you are not obliged to follow a text script or a narration script in order to cover a story. You have the freedom to tell a story... (LAMBERT, 2013, skype)

This is an innovation in aesthetic design and material formats, the elements of which include voice-overs, using excerpts from interviews, video graphics, accurate lighting, sound and visual effects, graphic features such as titles, 'eyes' (to add information and not just highlight it), newspaper fonts and colour patterns, all reinforcing the identity of FSP. The unfocused and experimental photography and ambient sound reminiscent of cine-documentary language are also of value - making up what Lambert (2013) defines as a "post 5D web-documentary", its trademark being the meaning and feeling behind the image:

I think that the use of images is not just illustrative. You have a whole bunch that you can do, think about photos as it is thought about in cinema, because you are not using the image simply as an illustration, and the camera you are using has other lighting features [...] the light gets out ... because TV cameras are appalling, they're limited [...] So, I think what we do different from the rest is that the image [...] you can build it how you want to. You can do this because our priorities and the way we work come from whoever puts it together, and not the reporter. This person ends up doing the job of screenwriter, editor and director. And there's a creative freedom when trying to emulate cinema, which ended up giving it its own language, which was what we were after (LAMBERT, 2013, skype). 
On the other hand, there are disadvantages to professional polyvalence: "you have a very heavy workload and carry a lot of responsibility on your shoulders, and you won't necessarily get more for it" (LAMBERT, 2013, skype). As much as this multifaceted profile sets a trend, forcing the professional to acquire new skills, you can't lose sight of its implications. In a capitalist society for example, the effects of technological convergence in journalism have caused layoffs, have turned some media outlets and functions inessential (mainly in printed press), and have caused a division of classes, competition and conflict among its actors. This argument can be applied to any social field as conceptualized by Bourdieu (2006) in his theory of social fields as a structured social space; fields of power occupied by the dominant and the dominated whose constant relations of inequality are acted out within this space which is also a battleground in the transformation or preservation of this field of power.

To ensure their space in the journalistic field many professionals end up yielding to the pressures of the market and expanding their skills. One example is the Labour Union for Television and Broadcasting Companies in Pará which recognizes new functions such as multimedia editor; a position that combines the previous tasks of videotape editors together with recording and screening. The nomenclatures of these once-separate functions are outmoded (because no one works with videotape in the digital age) and only multimedia editors have worked with them over the last two years or so. In the light of the work buildup, the editor's base salary went up by $40 \%$ - a measure taken in order to not break the code of ethics for journalists.

Moreover, the term multimedia is consistent with the convergence culture that journalism and its many processes of hybridization and multifaceted professionals are a part of. Keeping with this profile, director João Wainer (2012) at TV Folha believes that when photographers take on the role of cameraman, they are preparing themselves for the future of the market and guaranteeing their space.

For me, it is clear that the press, the magazines will have less circulation [...] When this happens, video will be just as important to newspapers as photographs are, or even more important than photographs. And it is important that photographers make this change, that they embrace video, so they don't need to be replaced by someone else who knows the language of video (WAINER, 2012, video). 
This anticipation for new times demonstrates the typical competitions and conflicts of a capitalist society and, consequently, of its social fields. According to Bourdieu (1997), the field of journalism (having taken form in the 19th century) would be a universe under constant pressure from the economic field and, therefore, commercial success would be the product's consecration; its recognition and legitimacy. From a capitalist viewpoint, journalism is a field of symbolic production with little autonomy, mainly due to the powers of oppression surrounding it such as economic influences and 'invisible' censorship that dictate the rules of the game. It is important to resist the "powers of oppression that diminish journalism - that journalism strikes back at all cultural production and, from there, all of society" (BOURDIEU, 1998, p. 109).

The kinds of pressure (economic, financial, technological, ideological, ethical, and moral) in a capitalist society lead many journalists to accept positions devoid of ethical commitment and based on sensationalism. Would the search to expand their professional skills come from the fear of being dismissed for only performing one function that would probably end up becoming obsolete due to technological advancement? Despite the dilemmas, the consensus in journalism has been the current need for journalists to know the ins and outs of each media form due to multiplatform production. At TV Folha, according to Wainer (2012), this differential lies in the fact that professionals from the printed press are working with video.

\footnotetext{
So, when filming, a photographer sees things differently from a cameraman. We interview the writer on the material he is doing, he doesn't look at the camera, and the photographer directs him while getting the narrative for the video. We don't use voice-overs as television journalism does - of course we have voice-overs, but they're taken from the interviews. So, the photographer ends up with the much greater responsibility of getting the necessary elements that a reporter would in order to tell the story (WAINER, 2012, video).
}

The resulting narrative from these changes in production is different from the conventional pattern of news shows; it builds up a video interview closely resembling the style used in "making of" documentaries. The reporter reports on what he saw, felt and understood about the fact, he writes on the street, in the newsroom or in the studio with no makeup and without 
looking at the camera. This strategy allows a reporter who has no experience with video to record a more natural piece, mediating and clearly breaking the myth of journalistic impartiality. In addition, it works as a pre-editing stage, capturing images and putting material together.

This freedom in constructing narratives allows for a longer duration, especially on the internet. When it was broadcasting on television, TV Folha had the same material in two distinct times: "sometimes, when there's no space in the grid, we put the full story on the internet. This is a shame because more people watch stories on TV than the internet." (LAMBERT, 2013, skype). The program also suffered other changes when it made the switch to television in 2012:

It turned into an actual system of production: there's a producer, people that capture video, editors and a program director. That's it. But the problem is that the newspapers are not used to this approach. They work individually and each one is responsible for their own part, they don't have that culture of understanding the collective function of the job. This isn't something newspapers have to do, but more what the people working behind TV Folha have to, and they realize that (LAMBERT, 2013 , skype).

\section{FROM MULTIFACETED PROFESSIONAL TO PROFESSIONAL EXPLOITATION}

TV Folha has few journalists. The team is made up of professionals in the fields of audio visual, cinema, mediology, and design. Reports can be made both by press reporters and by any one of the newspaper's professionals and follow the traditional patterns of television news, resembling documentaries. Other researchers are also aware of this similarity:

\footnotetext{
The reports are similar to mini documentaries. The material is edited not only with moving images but also photographs. Mixing photography and video in the same report is common. Having no voice-overs gives the viewer a greater freedom to interpret the information (ECHEVERRIA, 2012 , p. 8)
}

According to Wainer (apud Kachani, 2012), the idea of adopting less voice-overs and a new language was to create a contrast to conventional television journalism. What would this 
product be? For Wainer (2012, video), it would be "a new video production project using the format and language of documentaries within everyday journalism". In other words, it is a challenge of technological convergence by adopting cameras that capture both still and motion images producing a new visual aesthetic. In order to accomplish this there was a rule that the reporter could not be seen - we believe this was done to make it a little easier for those who came from newspapers to work on television. However, this began to change in less than a year after the show went on the air, pointing to another trend.

It will be closer to television news, because that's easier. I don't think this model (current) will go on much longer, unless there is a huge financial return, but that is difficult at TV Cultura they might stop doing TV. I don't like it when some reporters appear on television, it looks like CQC, this isn't what we're about, it is an escape (LAMBERT, 2013, skype)

Over time we have noticed that some reports really are similar to the model of television news mainly because press reporters who used to work at TV Folha felt more comfortable and secure in front of the camera. When the program went back to being broadcast exclusively online in April of 2014, the news reports put more of a focus on testimonial narratives as sources of information, going back once again to a documentary-style format.

In order to observe how production processes at TV Folha have developed, we analyzed the professional polyvalence of the crew and noticed that some news reports are made primarily by photographers ${ }^{5}$ as well as others which were made by photographers and newspaper reporters. There was the case of an aid (Rodrigo Machado) who was taking photos alongside photographers and afterwards signing off on them as his own. There was a professional (Márcio Neves) who was gathering photographs and news reports together, we even came across some photos which had been taken by the administrative secretary of advertising at TV Folha, Yago Metring. The author ${ }^{6}$ reveals in an interview the challenges around the program's production.

Everything becomes a challenge, just being a newspaper company means doing a television show is not easy. The team was made up of reporters, special reporters, photographers ... we didn't have any idea about the world of television, virtually no television experience, it was a big challenge for everyone - we are able to develop a great service with the help of the whole team and all the newspaper editors and the 
support of the newspaper. The reports are interesting, fun and investigative. Our focus has always been to make a newspaper that is different from any other (2013, METRING, online).

Outside of knowing how to film and conduct interviews, some photographers at TV Folha also act as video editors, leaning on the versatility of a polyvalent professional. "The difference is in the professional's ability to adapt and learn how to use the software, use final cut [editing software], use Adobe premier" (WAINER, 2012, video). He goes on to conclude that it is necessary for the professional to have at least four skills in order to work at TV Folha:

\begin{abstract}
Four skills the guy has to know to work with at TV Folha: the guy has to know how to photograph, shoot film, edit, and write. You don't need to know them all very well, there are a few that are better at one thing, some at others, but you have to have some knowledge of these four pillars at TV Folha. We joke around and say that each one has a super power. We have good editors who take the pre-cut material and put out a great product. (WAINER, 2012, video)
\end{abstract}

Polyvalence is also prevalent in the work of editors Douglas Lambert and André Felipe, who are responsible for the program standards and final cuts. Even still, Lambert (2013) explains that his main job is editing. There are materials he designates to editing, scripting, art or production. Afterwards, he does the photography, reporting and directs ${ }^{7}$. In addition to doing the final cuts André Felipe also edits. As for the art team, at least one member signs for the editing of the analysed material, in this case, Fabio Marra. Most of the editing team is also responsible for the screenplay.

When the program was on television his team consisted of: Melina Cardoso from the now defunct Folha Radio who narrated the videographic Folhacóptero; editor and host Fernando Canzian; and current director and photographer John Wainer who made his mark with the release of "June - the month that shook Brazil", a film addressing the manifestations of 2013 in Brazil. The director stated that he had always wanted to do a feature in the paper, believing that there was an opportunity for this: "we made and finalized the movie in the Folha newsroom. We learned the hard way" (WAINER apud OLIVEIRA, 2014).

The columnists at the program also worked for the press. Xico Sá (made audio visual stories) and Barbara Gancia (did surveys) 
were two of them. Both adopted a casualness and informality to their approaches. Another program columnist was Monica Bergamo. She talked about politics and participated in debates with other columnists and reporters from the newspaper. Other columnists such as writer Ricardo Feltrin from the Folha entertainment site F5 also worked on special events with TV Folha. Even having no television experience, Feltrin did a story with Douglas Lambert at the end of 2012 in Mexico. In fact, according to Lambert (2013), this was one of the few to have a pre-draft - something he wrote up on the way to Mexico.

According to Lambert (2013), pre-drafts are not very common because the program didn't have a special video team. That's why even reports written by press reporters had their scripts written by TV Folha. So, one could say that the program came about as a result of a hybrid of languages, formats and production processes, yet the fruit of professional polyvalence and convergence culture. It is important to note that the paradigm of convergence foresees the interaction between old and new media, favoring transmediality and the requisite of more knowledge, professional skill and creativity.

\footnotetext{
Unlike traditional media which is geared towards the demands of the industrial age, the inescapable move to digital platforms is changing network communication, the more horizontal structure of which drastically alters the relationship between subjects at various levels and the flows of communication (MÉDOLA, 2012, p. 191).
}

In the face of the numerous possibilities the internet offers and amid uncertainty about the future of television, Arlindo Machado (2011, p. 88) says that this is a time for challenges, trials and risks: "Everything indicates that we are witnessing the end of a television model and the beginning of experiences that are still unclear, yet significant enough to require research and analysis". As a constitutive element of contemporary times, television "unites individuals and the public who otherwise might be separated and offers them the possibility to collectively participate in building new relationships (WOLTON, 2012, p. 68).

In addition to the public participation mentioned earlier, new audience relationships changed the industry model of television. Now, there is no need to schedule a time to watch television. The internet allows the public to choose the time that suits them - without having to 
worry about recording their favorite programs. This is why since 2007 the U.S. networks "have been making their programming decisions based on a hybrid model that combines data on those who watched a show as it was being broadcast with those who watched it after" (JENKINS, 2009, p. 167). This is another great challenge for either those who produce content or for anyone who measures the audience.

Through the possibilities of interaction, Jenkins (2009) is able to explain how the different transmedia companies tell their stories across specific platforms and through public participation. The circulation of content over various media outlets depends on the consumer. TV Folha users have various ways of interacting on its site $^{8}$ such as "following on social networks like Facebook and Twitter, recommending, commenting and sharing links and/ or sending them by e-mail, increasing or reducing the font size of the text, reporting errors, copying the link and printing the text" (MARTINS, 2012, p. 104).

The program's transmediality is evident when producing on multiple platforms. When it was broadcast on television between March 2012 and April 2014, its material was reported and recorded almost always by the newspaper, but written by professionals from each platform. The program was structured in blocks with presenters, headlines and vignettes which blended advertising and cinema styles together. Its visual identity was similar to the FSP newspaper and it used a more informal language, one more suited for the internet. It showed longer versions of stories and included additional information on the internet. This allowed for distinct approaches to the same story, they could have different interviewees or even different snippets of interviews with one person, all building complementary and multiplatform narratives independent of each other.

Even though it is no longer broadcast on television anymore, the program maintains its transmediality in both multiplatform production (through audiovisual, printing press and the internet) and in encouraging the public to participate in social networks and sites from the Folha group.

The analysis of TV Folha shows that many challenges emerge with regard to convergence, but these challenges are more than just multi-platform content and a hybrid of languages, they are: the journalists' relationships with the public; their technical training and ethical values; the structure of the companies and 
their production-distribution forms and how they manage people; and the socio-communicative processes, especially in production. As Duarte (2012) so appropriately states, the fact texts nowadays displayed in multiplatform reveal the restrictions (and challenges) resulting from the current transformations - which certainly interfere with the way journalism is made and point towards transmedia as the new era of cultural industry.

\section{FINAL CONSIDERATIONS}

If transmedia is an expression of a new era in cultural industry expanding its niche in the market through media convergence, then it is also attracting new and potential consumers through different media. This reinforces how important it is to reflect on the impacts that hybrid processes have on journalism and on the conflicts of identity in this field. Convergence has led many journalists to take on more tasks that, in the past, used to be separated. This accumulation of tasks is a result of easier to use software or of the current popularization of more technical and economically accessible equipment. On the other hand, this could represent an increasingly appalling strategy that companies or even the labour market use to reduce their costs and increase their profits.

Outside of just trying to keep their jobs, are professionals also trying to keep up to date with the demands of the current generation? What about the code of ethics which says that heavier workloads are the exception? These are hard questions to answer, but this analysis led us to the conclusion that at TV Folha the heavier workload is handled by the team's make up: young, polyvalent professionals responsible for specific areas and able to perform several functions at the same time - a reflection of our contemporary (feeding the fragmented-integrated bipolar nature) and capitalist (market-based) societies. This profile is also a reflection of the technology behind contemporary equipment which makes multitasking possible.

Such transformations interfere directly in relations in journalism, especially in their production processes. As previously mentioned these new scenarios open the doors for journalism to embrace transmedia narratives and therefore set off multiple convergences: of media, formats, languages and professional skills 
which change relationships, practices and routines. Understanding changes in journalism leads to better understanding of the appropriations and construction of new narratives.

In addition, the fields also converge in contemporary times. In this analysis, we showed that TV Folha intentionally used elements of cinema, advertising and journalism whether for documentaries or advertising, giving it a hybrid language. Was this hybridism preferable because the news reports were almost always written by press reporters who did not possess any audio visual techniques? Or is it because photography is done by photographers or even video reporters? Is it because they use equipment that films and photographs? Or is it because the editor alone is responsible for writing the script? Does the question lie in editing or shooting film? Would a new language in Brazilian television journalism be born?

Whatever the answers might be, there is no doubt that all of these issues contribute to the construction of a new language of converging or conflicting looks and interests from social actors in journalism. A language that could be the result of an identity crisis within the field based on its integrated-fragmented bipolar nature which appropriates elements and narratives from other fields, maintaining the polyvalence dominating journalism in the digital age.

Previous studies (MARTINS, 2012) have helped us see TV Folha as an example of appropriation to transmedia narrative in journalism, which according to Jenkins (2009) is when a narrative migrates from one media form to another and, regardless of which form is chosen to access it, its message is still understood by the public. TV Folha news reports reinforce this idea which is usually press reports, but they present texts and sometimes even different characters from FSP, created by a team of polyvalent professionals in the three dimensions identified by Salaverría (2010), i.e.; functional, thematic and media.

As we have seen, heavy workloads affect the routine of the whole team: press reporters also work for the internet; cameramen film and take photos as well as direct and conduct interviews; the editor also takes photos, conducts interviews and writes scripts; the art team edits and does scripts, just like final cut editors do, who also capture video and direct. When the program was broadcast on television, press reporters also worked for TV Folha, the program 
host edited and conducted debates and columnists wrote material and participated in debates alongside the reporters, maintaining the self-referencing of this communication group.

Much as making non-segmented news in integrated newsrooms is a new trend forcing professionals to perform various functions at the same time, it is the difficulties and shortcomings of this modus operandi that have brought significant changes to journalism. Among these changes are the impacts on the identity of professionals in journalism, the status of the profession and the construction of new narratives which, together with a praxis inserted in convergence culture, develop new ways of contemporary narrating.

*This paper was translated by Lee Sharp.

\section{REFERENCES}

BOURDIEU, Pierre. Sobre a televisão. Trad.: Maria Lúcia Machado. Rio de Janeiro: Jorge Zahar, 1997.

Contrafogos - táticas para enfrentar a invasão neoliberal. Trad.: Lucy Magalhães. Rio de Janeiro: Jorge Zahar, 1998.

O poder simbólico. Trad.: Fernando Tomaz. 9a ed. Rio de Janeiro: B. Brasil, 2006.

DUARTE, Elizabeth Bastos. TELEVISÃO: novas modalidades de contar as narrativas. Revista Contemporânea, Salvador, UFBA/Poscom, v.10, n.2, p.324-39, mai-ago, 2012.

ECHEVERRIA, Renata. Considerações sobre o "TV Folha": um telejornal da Idade Mídia. In: SOCIEDADE BRASILEIRA DE ESTUDOS INTERDISCIPLINARES EM COMUNICAÇÃO, 35, 2012, Fortaleza. Anais... Fortaleza: Intercom, 2012, P. 1-12. Disponível em: http://www. intercom.org.br/papers/nacionais/2012/resumos/R7-0957-1.pdf. Acesso em: 03 set. 2014.

JENKINS, Henry. Cultura da Convergência. Trad.: Susana Alexandria. 2a ed. São Paulo: Aleph, 2009.

KACHANI, Morris. Folha na TV. Folha de São Paulo. São Paulo, 11 mar. 2012. llustrada, E1. 
LAMBERT, Douglas. Em entrevista concedida à autora no dia 06 de abril de 2013, via skype.

MACHADO, Arlindo. Fim da Televisão? Revista Famecos, Porto Alegre, PUC,v. 11, n.1,p. 86-97, jan-abr, 2011. Disponível em: http:// revistaseletronicas.pucrs.br/ojs/index.php/revistafamecos/article/ view/8799/6163

MARTINS, Elaide. Telejornalismo na era digital: aspectos da narrativa transmídia na televisão de papel. Brazilian Journalism Research, Brasília, SBPJor, v. 8, n. 2, p. 97-117, 2012.

MÉDOLA, Ana Silvia L. D. Produção e estética dos conteúdos televisivos em ambiente de convergência: o caso da TV Unesp. RBCC/Intercom, São Paulo, v.35, n.2, p. 189-204, jul./dez., 2012.

METRING, Yago. Em entrevista à autora através do Facebook em 5 de abril de 2013.

OLIVEIRA, Jéssica. "Fizemos o filme na redação da Folha. Aprendemos na raça", diz diretor de "Junho". Portal da Imprensa. São Paulo. 06 Jun. 2014. Disponível em: http:// www.portalimprensa.com.br/noticias/ultimas_noticias/66204/ fizemos+o+filme+na+redacao+da+folha+aprendemos+na+raca+diz+dire tor+de+junho Acesso em: 14 ago 2014.

PEREIRA JR, Alfredo Vizeu. Decidindo o que é notícia: os bastidores do telejornalismo. 4a ed. Porto Alegre: EDIPUCRS, 2005.

SALAVERRÍA, Ramón. Estructura de la Convergencia. In: Convergencia Digital: Reconfiguración de los Medios de Comunicación en España. Santiago de Compostela: Universidade de Santiago de Compostela, 2010, pp. $27-40$

TRAQUINA, Nelson. $\mathbf{O}$ estudo do jornalismo no século $\mathbf{X X}$. São Leopoldo, RS: Unisinos, 2001.

TV FOLHA vai concentrar vídeos na web. Folha de São Paulo. São Paulo, 13 abril 2014. Caderno Poder, A-14.

WAINER, João. Em entrevista aos organizadores do evento Mês da Fotografia em 14.08.2012. Brasília-DF: Sesc, 2012. Disponível em: http:// www.youtube.com/watch?v=Q9CSa_qV5kg Acesso em: 28 fev. 2013.

WOLF, Mauro. As teorias da comunicação. $5^{a}$ Ed. Lisboa: Presença, 1999.

WOLTON, Dominique. Internet, e depois? Trad. Isabel Crossetti. $3^{\text {a }}$ ed. Porto Alegre: Sulina, 2012. 


\section{NOTES}

1 Esso Award, Best contribution to Telejournalism; Aberje Award, Spotlight on television; and the Folha de Jornalismo Award, Special Category for coverage of the protests in Brazil in 2013.

2 This type of photo camera uses the concept of technological convergence defined by Jenkins (2009), predicting a combination of functions in one device. This device has been used a lot to capture images in movement due to its high performance and image quality. Even though the Nikon D90 was the first DLSR camera to capture video, the Canon 5D is a milestone in cameras as it is the first one to have digital cinema quality at an affordable price. It maintains its high performance even in low light, capturing and highlighting detail even in dark, shady areas. Another benefit are its interchangeable lenses which allows the lenses to be used in any situation.

3 An interview conducted by the event organization 'Mês da Fotografia', sponsored by SESC/DF in Brasilia from July 31 to Aug. 30, 2012 (www.mesdafotografia.blogspot.com), where João Wainer delivered a lecture on "Photo-Video and creating a new language: The TV Folha experience" on Aug. 08, 2012.

4 An interview conducted with the author on April 06, 2013 at 10am via skype. See Lambert's work at: http://www.douglaslambert.com.br

5 One example is cinematographer Fabio Braga's material shown on March 17, 2013. In an attempt to "experience relations between motorists and cyclists", he cycled $47.5 \mathrm{~km}$ through the streets of São Paulo with micro cameras attached to his bicycle and to his helmet, capturing images of himself and of the traffic. The interviews with the two motorists, one an urban transit consultant and the other bike courier entrepreneur, were recorded by colleague Felix Lima.

6 The author's responses to the questions sent on Facebook on April 5, 2013.

7 See Lambert's work at: http://www.douglaslambert.com.br

8 Website: www 1.folha.uol.com.br/tv 
Elaide Martins is doctor in Science (Environmental Development) from the Federal University of Pará, Master of Science Communication and Technology from the Methodist University of São Paulo and member of Facom and PPGCOM UFPA. Coordinates the GP Interactions and Technologies in the Amazon and integrates Applied Research Network in Journalism and Digital Technologies (JORTEC) 